\title{
Front Matter: Volume 7538
}

, "Front Matter: Volume 7538," Proc. SPIE 7538, Image Processing: Machine Vision Applications III, 753801 (17 February 2010); doi: 10.1117/12.853315

SPIE Event: IS\&T/SPIE Electronic Imaging, 2010, San Jose, California, United SPIE. States 


\title{
PROCEEDINGS \\ IS\&T/SPIE \\ Electronio \\ Imaging \\ Science and Technology
}

\section{Image Processing: \\ Machine Vision Applications III}

\author{
David Fofi \\ Kurt S. Niel \\ Editors
}

19-21 January 2010

San Jose, California, United States

Sponsored and Published by

IS\&T-The Society for Imaging Science and Technology

SPIE 
The papers included in this volume were part of the technical conference cited on the cover and title page. Papers were selected and subject to review by the editors and conference program committee. Some conference presentations may not be available for publication. The papers published in these proceedings reflect the work and thoughts of the authors and are published herein as submitted. The publishers are not responsible for the validity of the information or for any outcomes resulting from reliance thereon.

Please use the following format to cite material from this book:

Author(s), "Title of Paper," in Image Processing: Machine Vision Applications III, edited by David Fofi, Kurt S. Niel, Proceedings of SPIE-IS\&T Electronic Imaging, SPIE Vol. 7538, Article CID Number (2010).

ISSN 0277-786X

ISBN 9780819479310

Copublished by

SPIE

P.O. Box 10, Bellingham, Washington 98227-0010 USA

Telephone +1 3606763290 (Pacific Time) · Fax +1 3606471445

SPIE.org

and

IS\&T-The Society for Imaging Science and Technology

7003 Kilworth Lane, Springfield, Virginia, 22151 USA

Telephone +1 7036429090 (Eastern Time) · Fax +1 7036429094

imaging.org

Copyright (c) 2010, Society of Photo-Optical Instrumentation Engineers and The Society for Imaging Science and Technology.

Copying of material in this book for internal or personal use, or for the internal or personal use of specific clients, beyond the fair use provisions granted by the U.S. Copyright Law is authorized by the publishers subject to payment of copying fees. The Transactional Reporting Service base fee for this volume is $\$ 18.00$ per article (or portion thereof), which should be paid directly to the Copyright Clearance Center (CCC), 222 Rosewood Drive, Danvers, MA 01923. Payment may also be made electronically through CCC Online at copyright.com. Other copying for republication, resale, advertising or promotion, or any form of systematic or multiple reproduction of any material in this book is prohibited except with permission in writing from the publisher. The CCC fee code is $0277-786 \mathrm{X} / 10 / \$ 18.00$.

Printed in the United States of America.

Paper Numbering: Proceedings of SPIE follow an e-First publication model, with papers published first online and then in print and on CD-ROM. Papers are published as they are submitted and meet publication criteria. A unique, consistent, permanent citation identifier (CID) number is assigned to each article at the time of the first publication. Utilization of CIDs allows articles to be fully citable as soon they are published online, and connects the same identifier to all online, print, and electronic versions of the publication. SPIE uses a six-digit CID article numbering system in which:

- The first four digits correspond to the SPIE volume number.

- The last two digits indicate publication order within the volume using a Base 36 numbering system employing both numerals and letters. These two-number sets start with 00, 01, 02, 03, 04, 05 , 06, 07, 08, 09, OA, OB ... 0Z, followed by 10-1Z, 20-2Z, etc.

The CID number appears on each page of the manuscript. The complete citation is used on the first page, and an abbreviated version on subsequent pages. Numbers in the index correspond to the last two digits of the six-digit CID number. 


\section{Contents}

vii Conference Committee

\section{SESSION 1 INDUSTRIAL INSPECTION AND APPLICATIONS}

753803 Rotating optical geometry sensor for inner pipe-surface reconstruction [7538-02]

M. Ritter, C. W. Frey, Fraunhofer Institute of Optronics, System Technologies and Image Exploitation (Germany)

753804 Fully automatic leaf characterisation in heterogeneous environment of plant growing automation [7538-03]

G. Chareyron, J. Da Rugna, A. Darsch, Pôle Univ. Léonard de Vinci (France)

753805 3D vision for nuclear reactor retrofit tool docking [7538-04]

J. Stavnitzky, F. Rivollier, ATS Automation Tooling Systems Inc. (Canada)

\section{SESSION 2 ACTIVE VISION AND ROBOTICS I}

753806 Analysis of a multimodal-camera and its advantages for autonomous vehicles [7538-05] S. Hawe, U. Kirchmaier, K. Diepold, Technische Univ. München (Germany)

$753807 \quad$ Fully automatic 3D digitization of unknown objects [7538-06]

G. F. Rozenwald, R. Seulin, Y. D. Fougerolle, LE2I, CNRS, Univ. de Bourgogne (France)

753808 Automatic trajectory clustering for generating ground truth data sets [7538-07]

J. Moehrmann, G. Heidemann, Univ. Stuttgart (Germany)

753809 VisNAV 100: a robust, compact imaging sensor for enabling autonomous air-to-air refueling of aircraft and unmanned aerial vehicles [7538-08]

A. Katake, StarVision Technologies, Inc. (United States); H. Choi, Texas A\&M Univ. (United States)

\section{SESSION 3 PHYSICAL IMAGING AND MICROSCOPY}

$7538 \mathrm{OB}$ Comparison of the ability of quantitative parameters to differentiate surface texture of Atomic Force Microscope (AFM) images [7538-10]

B. Niedzielski, Rensselaer Polytechnic Institute (United States); C. Caragianis Broadbridge,

J. S. DaPonte, M. Gherasimova, Southern Connecticut State Univ. (United States)

7538 OC Conformity of valuable spikes by ombroscopic imaging [7538-11]

F. Mairesse, T. M. Sliwa, Y. Voisin, LE21, Univ. de Bourgogne (France)

7538 OD Segmentation of thermographic images of hands using a genetic algorithm [7538-12] P. Ghosh, M. Mitchell, Portland State Univ. (United States); J. Gold, Temple Univ. (United States) 
$7538 \mathrm{OE}$ A system architecture for online data interpretation and reduction in fluorescence microscopy [7538-13]

T. Röder, Technische Univ. München (Germany); M. Geisbaver, Biolmaging Zentrum der LMU (Germany); Y. Chen, A. Knoll, Technische Univ. München (Germany); R. Uhl, Biolmaging Zentrum der LMU (Germany)

\section{SESSION 4 MULTISPECTRAL IMAGING}

7538 OF Motion estimation accuracy for visible-light/gamma-ray imaging fusion for portable portal monitoring [7538-14]

T. P. Karnowski, Oak Ridge National Lab. (United States); M. F. Cunningham, Lawrence Livermore National Lab. (United States); J. S. Goddard, A. M. Cheriyadat, D. E. Hornback, L. Fabris, R. A. Kerekes, K.-P. Ziock, Oak Ridge National Lab. (United States); T. F. Gee, Aldis Inc. (United States)

7538 OG A novel approach for the fusion of combined stereo and spectral series [7538-15] I. Gheța, S. Höfer, Karlsruhe Institute of Technology (Germany); M. Heizmann, Fraunhofer IOSB (Germany); J. Beyerer, Karlsruhe Institute of Technology (Germany) and Fraunhofer IOSB (Germany)

\section{SESSION 5 3D VISION AND RANGE IMAGING}

7538 ol Multiple range imaging camera operation with minimal performance impact [7538-17] R. Z. Whyte, A. D. Payne, A. A. Dorrington, M. J. Cree, The Univ. of Waikato (New Zealand)

7538 0J Calibration and control of a robot arm using a range imaging camera [7538-18] C. B. D. Kelly, A. A. Dorrington, M. J. Cree, A. D. Payne, The Univ. of Waikato (New Zealand)

7538 OK Resolving depth-measurement ambiguity with commercially available range imaging cameras (Best Student Paper) [7538-19]

S. H. McClure, M. J. Cree, A. A. Dorrington, A. D. Payne, The Univ. of Waikato (New Zealand)

$7538 \mathrm{OL} \quad$ A novel 3D reconstruction approach by dynamic (de)focused light [7538-20]

I. Lertrusdachakul, Y. D. Fougerolle, O. Laligant, LE2I, CNRS, Univ. de Bourgogne (France)

\section{SESSION 6 ACTIVE VISION AND ROBOTICS II}

7538 OM 1000-fps real-time optical flow detection system [7538-21]

I. Ishii, T. Taniguchi, K. Yamamoto, T. Takaki, Hiroshima Univ. (Japan)

7538 ON Motion-based situation recognition in group meetings [7538-22]

J. Moehrmann, X. Wang, G. Heidemann, Univ. Stuttgart (Germany)

$753800 \quad$ Motion detection with level set-based segmentation [7538-23]

S. Lee, N. Choi, Dongseo Univ. (Korea, Republic of); M. G. Kang, Yonsei Univ. (Korea, Republic of) 
7538 OP Ego-translation estimation from one straight edge in constructed scenes [7538-24] S. Mosaddegh, D. Fofi, LE2I, CNRS, Univ. de Bourgogne (France); P. Vasseur, MIS, Univ. de Picardie Jules Verne (France)

\section{SESSION $7 \quad$ IMAGE PROCESSING AND ALGORITHMS}

$7538 \mathrm{OQ}$ A line detection and description algorithm based on swarm intelligence [7538-25]

U. Kirchmaier, S. Hawe, K. Diepold, Technische Univ. München (Germany)

7538 OR A hybrid and adaptive segmentation method using color and texture information [7538-26]

C. Meurie, Y. Ruichek, A. Cohen, Univ. of Technology of Belfort-Montbeliard (France);

J. Marais, INRETS, LEOST, Univ. Lille Nord de France (France)

7538 OS Hierarchical feature extraction and object recognition based on biologically inspired filters [7538-27]

P. Mishra, B. K. Jenkins, Univ. of Southern California (United States)

7538 OU Blurred face recognition algorithm guided by a no-reference blur metric [7538-29]

C. Fiche, P. Ladret, N.-S. Vu, Gipsa-Lab. (France)

7538 OV 2×1D image registration and comparison [7538-38]

G. Zheng, E. H. Barney Smith, N. Rafla, T. Andersen, Boise State Univ. (United States)

\section{INTERACTIVE PAPER SESSION}

7538 OY Layer separation for material discrimination cargo imaging system [7538-32]

K. Fu, Univ. of California, San Diego (United States); D. Ranta, SAIC (United States); P. Das,

C. Guest, Univ. of California, San Diego (United States)

$75380 Z$ The application of wavelet denoising in material discrimination system [7538-33]

K. Fu, Univ. of California, San Diego (United States); D. Ranta, SAIC (United States); C. Guest, P. Das, Univ. of California, San Diego (United States)

753810 A practical DCT based blind image watermarking scheme for print-and-scan process [7538-34]

J. Jin, H. Hou, Y. Xiong, Hewlett-Packard Labs. China (China)

753812 Synthesis of solid textures based on a 2D example: application to the synthesis of 3D carbon structures observed by transmission electronic microscopy [7538-36]

J.-P. Da Costa, C. Germain, IMS Lab., CNRS (France) and ENITAB, Univ. of Bordeaux (France)

753813 Cigarette smoke detection from captured image sequences [7538-37]

K. Iwamoto, H. Inove, T. Matsubara, T. Tanaka, Tokyo Univ. of Agriculture and Technology (Japan)

Author Index 
Downloaded From: https://www.spiedigitallibrary.org/conference-proceedings-of-spie on 26 Apr 2023

Terms of Use: https://www.spiedigitallibrary.org/terms-of-use 


\title{
Conference Committee
}

\author{
Symposium Chair
}

Jan P. Allebach, Purdue University (United States)

Symposium Cochair

Sabine Süsstrunk, Ecole Polyłechnique Fédérale de Lausanne

(Switzerland)

Conference Chairs

David Fofi, Université de Bourgogne (France)

Kurt S. Niel, Fachhochschule Wels (Austria)

Program Committee

Philip R. Bingham, Oak Ridge National Laboratory (United States)

Pierrick T. Bourgeat, Australian e-Health Research Center (Australia)

Jun Cheng, Chinese Academy of Sciences (China)

Michael J. Cree, The University of Waikato (New Zealand)

Marc M. Ellenrieder, Carl Zeiss Optronics GmbH (Germany)

Lixin Fan, Nokia Research Center (Finland)

Ewald Fauster, vatron $\mathrm{GmbH}$ (Austria)

Steven P. Floeder, 3M Company (United States)

Luciano F. Fontoura Da Costa, Universidade de São Paulo (Brazil)

Edmund Y. Lam, The University of Hong Kong (Hong Kong, China)

Xavier Llado, Universitat de Girona (Spain)

Fabrice Meriaudeau, Université de Bourgogne (France)

Dinesh Nair, National Instruments Corporation (United States)

Jeffery R. Price, Oak Ridge National Laboratory (United States)

A. Ravishankar Rao, IBM Thomas J. Watson Research Center (United States)

Hamed Sari-Sarraf, Texas Tech University (United States)

Ralph Seulin, Université de Bourgogne (France)

Yvon Voisin, Université de Bourgogne (France)

\section{Session Chairs}

1 Industrial Inspection and Applications

Kurt S. Niel, Fachhochschule Wels (Austria)

2 Active Vision and Robotics I

David Fofi, Université de Bourgogne (France) 
3 Physical Imaging and Microscopy

David Fofi, Université de Bourgogne (France)

$4 \quad$ Multispectral Imaging

Kurt S. Niel, Fachhochschule Wels (Austria)

$53 \mathrm{D}$ Vision and Range Imaging

David Fofi, Université de Bourgogne (France)

6 Active Vision and Robotics II

David Fofi, Université de Bourgogne (France)

$7 \quad$ Image Processing and Algorithms

Kurt S. Niel, Fachhochschule Wels (Austria) 